\title{
Retailing Elements That Break Customer Restraints: A Conjoint Analysis Approach
}

\author{
*Mario C. Angeles, Fernando Trinidad \\ The Graduate School, University of Santo Tomas, España Boulevard, Sampaloc, Manila, Philippines \\ * Corresponding Author
}

\begin{abstract}
Traditional retailing remains to be the most utilized platform for fast-moving consumer goods transactions. The need to understand the dynamics between the physical retail stores and how it affects consumer behavior is still of utmost importance. The study aims to determine retailing elements that are most influential in terms of increased spending. The study led to the following insights: on a noncontrolled and controlled environment in terms of spending cap, the most prominent retailing element in terms of influence is the presence of directional signages with the degree of importance at 25.08 and 22.38 respectively, while in a controlled environment, high level of product assortment follows with the degree of importance at 16.47. As a point of parity between the two spending environments, presence of product bundle as a retail element, replacing the high level of product assortment, is influential on uncapped spending scenario with the degree of importance at 21.88 , while being one of the least influential in capped spending with the degree of importance at 6.26. The results were gathered via conjoint analysis statistical method covering eight distinct retail elements through a nationwide sampling dispersal.
\end{abstract}

Keywords: promotion, atmospheric, point-of-purchase display, value-added service, purchase behavior, conjoint analysis, fast-moving consumer goods, retailing

\section{Introduction}

In a supermarket environment, the initial orientation of customers is to stay only for a short period of time (Hynes and Manson, 2016). Hynes and Manson (2016) even stressed that supermarket customers focus on price of the items, what products to buy, and the limited time they spend when shopping. However, manufacturers and retailers use various in-store touchpoint elements such as promotions, atmospherics, point-of-purchase displays, and some forms of value-added services to facilitate shoppers, increase customer responses and emotions, and motivate them to buy. Thus, manufacturers and retailers collaborate in maximizing the use of some of these elements that increase customer foot traffic (Kuntner and Teichert, 2016) and affect or alter their buying decisions (Platania et 
al., 2016; Grosso et al., 2018; Breugelmans \& Campo, 2016; Helmefalk \& Hultén, 2017; Diels et al., 2013).

Previous studies examined the significant impact of various in-store touchpoint elements to customer's decision-making when shopping. Moreover, existing literatures show how these elements influence customers to buy, leading to an increase in sales and profit due to more spending of the customers inside the store. Interestingly, most customers are more attracted to buy from a store when these touchpoint elements are present. These customers spend even more time and money when exposed to these elements. Thus, the researchers investigated the customer's buying behavior using these in-store touchpoint elements under capped and uncapped spending scenarios.

This study examined the most influential variables affecting grocery shoppers in terms of capped and uncapped spending and support unplanned or impulse buying strategies' efficacy with a guarantee that the chosen variable is outstandingly delivered. In a bigger perspective, this study examined the gap between the in-store touchpoint elements affecting customer's buying behavior and the efficacy of collaborative efforts of manufacturers and retailers to entice the consumers to buy. These were achieved using conjoint analysis method in processing a collection of data from random respondents where they ranked a set of cards or alternatives, each describing a full attribute set.

On a capped spending scenario, the presence of directional signage, high level of product assortment, wide isles on store layout and high level of replenishment rate prime the customers when shopping inside the store. Nonetheless, the four most influential retail elements for customers when shopping on uncapped spending scenario are the presence of directional signage, presence of product bundle, high level of product assortment and high level of replenishment rate. Although the most preferred element by the customers is still the presence of directional signage on uncapped spending, the presence of product bundle replaced the high level of product assortment in this scenario. This shows how important the directional signage is to customers when shopping inside the store both on capped and uncapped spending. This is not surprising because the customer's familiarity with the store's trading floor is crucial in achieving their shopping goals. Moreover, even though high level of product assortment is significant for the customers when shopping in a capped spending scenario, presence of product bundle is more important to the customers on uncapped spending. This shows how responsive and vulnerable the customers are on promotional tools such as product bundle when there is no spending limit.

The study focused on physical retailing elements in the Philippines. Price and discount considerations are attached to products and determined by the manufacturer more than the retailer. Price-related elements were not included due to the obvious impact of these to purchase decisions which will defy the purpose of determining the most influential retailing elements in terms of capped and uncapped spending. Therefore, the researchers limit their study on non-price items only and their impact to the purchase decisions of the Filipino consumers.

Moreover, the study emphasized the brick-and-mortar store set-up. Although the electronic commerce is widespread in almost all types of goods and online buying is increasing, a significant 
number of Filipino consumers still adhere to the traditional way of buying grocery items (Euromonitor, 2019a). This can be observed from the growing number of supermarkets nationwide (Euromonitor, 2019b). Thus, it is interesting to investigate the buying decisions of the consumers and the impact of non-price elements in the brick-and-mortar store in the era of e-commerce.

\section{2- Discussion}

The primary reason why customers spend more is due to the importance of what the shopper is buying, not because of the hedonic value, such as shopping experience (Chebat et al., 2014). Nevertheless, there are various in-store elements that affect customers' decision when buying a product even they already have a preferred brand in mind (Scriven et al., 2017). Most of these in-store elements affect the customers' decision to buy (Kukkar-Kinney \& Carlson, 2015; Atulkar \& Kesari, 2017; Berman \& Evans, 2010; Loureiro \& Roschk, 2014; Michel et al., 2017; Chebat et al., 2014; Poncin \& Ben Mimoun, 2014; Kumar \& Kim, 2014; Vilches-Montero et al., 2018; Rayburn \& Voss, 2013; Roschk et al., 2017; Grosso et al., 2018; Shimp \& Andrews, 2014b; Hoek et al., 2017; Behe et al., 2015; Gao \& Simonson, 2016). Hence, it is interesting to know and understand the behavior of the Filipino consumers when manufacturers and retailers of fast-moving consumer goods (FMCGs) deploy these touchpoint elements collaboratively and how the consumers respond to these if such elements exist in the store.

\subsection{Product Sample}

The use of promotion is costly and requires extensive campaigns (Bayer and Ke, 2013). Some of these promotions include point-of-purchase (POP) displays, product demonstration, free samples, coupons, price-off or percent-off, contests, games, rebates, refund, frequent buyer rewards, raffle, and premiums or bundle (Pride et al., 2013). Bogomolova et al. (2017) stressed that, for the firm, promotions' main goal is a short-term increase in revenues only. Nonetheless, promotions influence or motivate customers to purchase certain products from a store (Pride et al., 2013). In fact, (Lu et al., 2017) stressed that purchases constantly increase when promotions are given. For instance, (Yao et al., 2017) argued that product sampling, a type of promotion, increases sales of popular brands, same as non-popular brands. Moreover, (Lu et al., 2018) stressed that potential customers not yet loyal to the brand and who purchase moderately are receptive to product sample and spend more after receiving it. Furthermore, promotion has no adverse effect on customer's possibility to repeat the purchases (Kuntner and Teichert, 2016).

\subsection{Product Bundle}

Dynamic bundling exists when the main product is packed together with another product while altering their prices ( $\mathrm{Li}$ et al., 2018). On the other hand, promotions in a form of packages containing dissimilar products stimulate consumers to buy and amplify sales (Liu \& Chou, 2015). Liu and Chou (2015) even stressed that it is better to use promotional bundle in a form of free gift to create a high level of repurchase intentions of consumers due to their perceived price increase when such promotion expires. Liu and Chou (2015) also argued that customers perceive fairness and lessen their comparison between transactions when dynamic bundling is offered compared to price bundling. For bundling to be 
successful, the products complementing the promoted product require a high level of complementarity and the promotion must be enticing to customers (Yan et al., 2014). Yan et al. (2014) even stressed that advertised bundling scheme gives better performance than those of non-advertised bundling approach.

\subsection{Store Layout}

Atmosphere or atmospheric is the appearance of the store that signifies its image and is being used to attract customers (Berman \& Evans, 2010). It is a distinguishable component of shoppers' instore experience (Stein \& Ramaseshan, 2016). In-store environmental elements serve as emotions' initial moderator that arouses customers and influences purchasing behavior (Platania et al., 2016). As stated by the theory of environmental psychology, Chebat et al., (2014) argued that for shoppers to perform more information processing and explore the store further, they must be aroused positively by the environment favorable to their shopping. Additionally, customers' satisfaction is positively affected by the in-store atmospheric elements leading to increased shopping experience and some level of buying behavior (Grosso et al., 2018). Moreover, in-store atmospheric elements, tangible or not, play a significant and important role in the shopping experience of the customers (Terblanche, 2018) because they normally evaluate these prior to shopping (Berman \& Evans, 2010) and customers have high expectations when entering a store while they look for shopping experience (Loureiro \& Roschk, 2014). Accordingly, atmospherics make the store more competitive and increases positive customer responses which then lead to higher customer engagement (Foster \& McLelland, 2015).

Store design, one type of atmospheric element favorable to customers' attitude, has a significant effect on shoppers' comfortable feeling (Ainsworth \& Foster, 2017). The study of Atulkar and Kesari, (2017) revealed that when customers are highly satisfied with the shopping experience due to in-store atmospheric components, customers' loyalty to the store and repurchase intention increase. Moreover, the use of ambience created by the store is important to customers that leads to their intention to buy from the store and spend more (Loureiro \& Roschk, 2014). For instance, (Pantano, 2016) argued that technologies with customer interaction, informative, and entertaining features placed at the storefronts can catch the attention of the customers and facilitate more shopping. Additionally, when a store uses digital technology, it adds value both to the store and the shopper and increases the attractiveness of the store's atmospheric components (Poncin \& Ben Mimoun, 2014). However, Garaus et al., (2015) argued that atmospheric components in the store influence confusion among customers. Garaus et al. (2015) further argued that when shoppers experience confusion inside the retail store due to incongruity, it affects their feelings which, in turn, lower shopping experience. Differentiation in terms of atmospherics is crucial in retail stores because shoppers recognize in-store atmospheric elements as a whole which motivates them to shop more at the store (Rayburn \& Voss, 2013). Although it is not often easy to alter the store's environment, such as layout, it is crucial that store environment be designed suitably to increase customers' arousal even in moderate level at the very least (Vieira \& Torres, 2014). Chebat et al. (2014) even stressed that when renovating atmospheric elements, it should be noted that the design must not only be just desirable but also help shoppers accomplish their shopping tasks and encourage more spending. 


\subsection{In-store Music}

Although intangible, another example of an atmospheric element present in a retail store is music. Music affects shoppers' mood (Furnham \& Milner, 2013) and has both negative and positive impact to customers' emotions and behavior depending on what type of music is being played (Michel et al., 2017). However, this type of environment must only be used for customers who are recreationfocused (Vieira \& Torres, 2014). For instance, Kumar and Kim (2014) argued that the choice of music affects the shoppers' perception of the store positively. Michel et al., (2017) even stressed that music being liked by customers, particularly those which are familiar to them, have positive responses. Moreover, music has a significant impact on duration of customers' shopping time which, in turn, leads to some purchase behavior (Helmefalk \& Hultén, 2017). In fact, customers' choice of products and ease of remembering the product increase due to the influence of music compatible with customers' characteristics and, in turn, amplifies the customers' amount of willingness to pay (North et al., 2016). Interestingly, the study of (Michel et al., 2017) revealed that customers show positive emotions (i.e., arousal level) and express intention to buy when fast and loud music is being played. Michel et al. (2017) even suggested that music at low rhythm and sound volume must be used, music liked by customers must be played such as music they are familiar with, and music must fit the store setting to increase sales and customers' time spent inside the store. Thus, music has total effects on pleasurable shopping experience and intention to buy (Roschk et al., 2017). Nonetheless, customers in supermarkets are not essentially mindful of music inside the store and music does not influence them because most supermarket customers who happen to visit the store consider shopping in the supermarket as a chore rather than shopping experience (Hynes \& Manson, 2016). Additionally, if there is an incongruity between the music being played and the store itself, shoppers will manifest adverse perceptions about the store (Kumar \& Kim, 2014).

\subsection{Directional Signage}

Point-of-purchase (POP) communications consist of several forms which include signage, instore banners, shelf advertising (or talkers), product displays, wall posters, floor ads, checkout items, mannequins, etc., (Shimp \& Andrews, 2014a). These collaterals influence shopping behavior through facilitation due to information provision (Lawley et al., 2016). Shimp and Adnrews (2014a) stressed that manufacturers use POP communication materials to maintain the brand name of the company and the brand itself as well as attract shoppers and trigger purchase on impulse, while retailers use POP display to increase shopper attention, shopping intentions, and time spent inside the store to increase foot traffic and sales. On the other hand, Shimp and Andrews, 2014a argued that for shoppers, POP displays are essential tools to get information about the products, facilitate shopping and make their decision-making process much easier. For instance, when customers are not familiar with the store's trading floor and are facilitated with extensive viewing pattern such as placing large digital signs to a certain aisle, they automatically display store familiarity behavior (Otterbring et al., 2016). In fact, priming on customer perceptions using signage with relevant information inside the store has a significant effect to the shoppers' attention, provides enough information to the shoppers and simplifies locating the items within the store (Otterbring et al, 2014). 


\subsection{Shelf Talker}

Clement et al. (2013) stressed that creating preliminary customer attention, such as POP communication, is crucial in stimulating purchase intention. Wang and Lang (2015) even argued that the primary goal of in-store special display is to send messages to customers and activate shoppers' perceptive means of evaluating a product before buying it. POP communication is the perfect timing for manufacturers and retailers to communicate with shoppers because evaluation and decisions are done exactly at the time when shoppers are inside the store (Shimp \& Andrews, 2014a). As a matter of fact, communication content in a text form that provides facts about the product through POP display attracts the customers' attention leading to purchase probability (Behe et al., 2015). Interestingly, even digital signage and content affecting customers' emotions positively form pleasurable shopping experiences leading to impulsive buying and customers' patronage to the store (Garaus et al., 2017). Moreover, new technology used by the store affects customers' perceptions about the store leading to their intention to patronize the store in the future time and their desire to create favorable word-of-mouth regarding the store (Inman \& Nikolova, 2017). Furthermore, POP undertakings such as message content modification can highly influence shoppers to a big switch from one product to another and their intention to purchase (Hoek et al., 2017). Wang and Lang (2015) even stressed that purchase behavior is highly influenced by special displays when, in the remaining time of their visit, customers are exposed to these displays at the entry point of the store. However, usage of various collaterals for point of sale depends on the target customers the store wants to attract (Lawley et al., 2016) because distinct generation groups differ from one another in terms of values, attitude and preferences which can affect their buying habits (Parment, 2013). Consequently, from various display design options, mass production of the best design must be done and place them on the right areas of the store to attract shoppers even more from the product display being promoted (Horstmann, 2017). Moreover, Pantano and Viassone (2014) even argued that some customers are not completely satisfied with the retailer's use of new technology in their point of sale. Pantano and Viassone (2014) even pointed out that customers must be informed about the benefits of using the new technologies in the store, such as better communication facilitation and shopping experience.

\subsection{Replenishment Rate}

Retailers' provision of service outputs or value-added services is crucial for manufacturers in designing channel structure and selecting channel members (Coughlan et al., 2010). Coughlan et al. (2010) also argued, considering the product and price being constant, customers favor those retail stores that provide a high level of value-added services, one of which is the time of delivery or waiting time. Moreover, Vyt et al., (2017) stressed that creativity and innovativeness of the store that affects customers' level of satisfaction are necessary for creating an emotional impact to sensory pleasure and cognitive stimulation of the customers. When customers are highly satisfied with exceptional customer services, customers' loyalty to the store and repurchase intention increase (Atulkar \& Kesari, 2017). For instance, customers' decision-making satisfaction decrease and repurchase intentions decline when product items that attract them are not available (Pizzi \& Scarpi, 2013). In fact, during an out-of-stock situation, customers' attention shifts to product options with relative attributes of the product items not 
available in the store which leads to increase in sales of product options especially if the product options are noticeable (Huang \& Zhang, 2016). However, right timing and communication may counterweight the customers' negative thoughts and buying behavior during the out-of-stock situations (Pizzi \& Scarpi, 2013).

\subsection{Product Assortment}

Another value-added element, product variety or assortment, plays a significant role in customer choice and provides value to them, leading to a positive mood due to customers' satisfied needs (Terblanche, 2018). Although diverse, it is worth noting to understand the customer's preference for product assortment. For example, customers in positive mood develop a perception of variation of dissimilarity among small and huge selections which mean these types of customers do not encounter difficulties in choosing product items compared to neutral mood customers (Spassova \& Isen, 2013). Beneke et al., (2013) even argued that customers' perception of the reduced number of assortments is not affected when the store retains the most favored items. On the one hand, amateur customers' processing method in selecting a complex item is not affected positively by the existence of classes of product variety (Langner and Krengel, 2013). Interestingly, customers are more inclined to buy an item from a larger size of selection with a mind-set of 'buying first' which overpowers the decision of 'selecting first' (Gao \& Simonson, 2016). Nevertheless, Chan (2015) stressed that customer contentment decreases if there are too many attractive product items to choose from due to increased feeling of regret, while contentment increases if there are too many unattractive product items due to customers' reduced regret. Yan et al., (2015) even argued that too many categories in the shelves, whether there are many or few options, may increase customers' satisfaction to some extent, but will eventually drop due to selection overload which results from regretting from choosing.

\subsection{Research Method}

The study used conjoint analysis in processing a collection of data to address (1) what attributes of product/service/program are important and unimportant to the people and/or (2) what levels of the attributes of product/service/program are the most or least desirable in the people's mind. It presents choice alternatives between products/services/program defined by sets of attributes. Full-profile conjoint analysis method was used where the respondent ranks a set of cards or alternatives, each described by a full attribute set presenting a full profile of each alternative.

\subsection{Subjects and Study Site}

The study was conducted in three highly urbanized cities in the Philippines-Manila City, Cebu City, and Davao City, with a total sample size of 600 respondents. These respondents are household consumers who regularly visit a supermarket. Orme (2010) suggests that when using conjoint analysis, at least 200 sample size is necessary per group to test the significant differences among groups or 200 sample size times the number of segments if segmentation analysis on the preferences will be conducted. Each city represents each region where these cities belong - Manila City in National Capital Region or NCR, Cebu City in Central Visayas Region, and Davao City in Davao Region. Each region represents 
three major island groups of the Philippines namely: (1) NCR for Luzon group of islands, (2) Central Visayas Region for Visayas group of islands, and (3) Davao Region for Mindanao group of islands. Cebu City and Davao City are the most urbanized cities in Visayas and Mindanao group of islands respectively. Though second most urbanized in Luzon group of islands and in NCR, next to Quezon City, Manila City is the capital city and the seat of trade of the Republic of the Philippines. The reasons for choosing household consumers as respondents instead of the trading area customers or actual shoppers are (1) to avoid decided shopper prospective bias, (2) to avoid getting in contact with a respondent who is already decided on a product and who is already on his/her way topic-up the said product, and (3) to acquire the respondents' objectivity without the presence of the variables identified in the study.

\subsection{Research Instrument}

Sixteen cards, as shown in Table 1, were created using SPSS representing a combination of the retail store elements and their dimensions on each card. Product sample (present, absent) is a value that does not require purchase a consumer will enjoy even without buying an item, while a product bundle (present, absent) is a value that requires purchase before a consumer enjoys the free item. Store layout (wide aisles, narrow isles) is an active atmospheric variable (a foreground set-up), while in-store music (present, absent) is a passive atmospheric variable (a background set-up). Directional signage (present, absent) is a route variable leading to the product category, while a shelf talker (present, absent) is a destination variable highlighting the presence of and information about a particular brand. Replenishment rate (high, low) is a variable that points toward a single product, while product assortment (high, low) is a variable that points toward multiple products.

The plancards were used for the two batches of household respondents - 300 respondents for batch 1 and 300 respondents for batch 2 . For batch 1, the study investigated the most influential variables affecting grocery shoppers in terms of capped spending, while for batch 2, the study examined the same in terms of uncapped spending while supporting the unplanned or impulse buying strategies' efficacy with a guarantee that the chosen variable is outstandingly delivered. The set of plancards is a combination of touchpoint elements and dimensions involved in the study. Two industry practitioners and two academicians were consulted for the validity of the instruments to be used. Subsequently, few modifications of the instruments were made. Data collection were accomplished after the test for reliability using the holdout plancards 13 to 16 as indicated in Table 1 . These plancards were a combination of cards created by SPSS.

\subsection{Data Gathering Procedures}

A random survey was administered in household-to-household basis using a snake-like pattern skipping two households in-between. This means that the next respondent will come from the third household from the most previous household. The total sample size of each city was divided on a prorata basis. The total sample size per city was divided into four clusters. Each cluster includes north, south, east and west of the city. The areas on each cluster were chosen randomly using a lottery. After identifying the household and the respondent agreed for a survey, a screening question was asked: "Do 
you regularly buy from a supermarket?" If the respondent's answer is no, the survey was terminated, and the researchers proceeded to the next household. However, if the answer is yes, the respondent was asked about little information regarding his/her profile.

The respondent's profile includes region, age range, gender, and frequency of visit to a supermarket. The researchers provided and explained to the respondent the following: (1) conjoint plancards to be used for ranking, (2) respondent's guide to touchpoint elements, and (3) reference to plancard. The researchers showed the set of plancards to respondent and asked the question: "Which among the conditions of grocery shopping do you prefer? Please arrange from the most preferred to the least preferred." The sets of laminated plancards were handed over to the respondent and gave the respondent some time arranging the cards from the most preferred to the least preferred on top of the other showing only the card code and respondent number or code. Then, the researchers wrote the respondent's number on the most preferred card using a white board marker. A picture was taken for future encoding of the ranked set of cards. Here, the top plancard is the best in mind or most preferred. After taking a picture, the researchers proceeded to the next respondent and end the procedure after the last target respondent number.

\subsection{Data Analysis}

Orthoplan procedure of SPSS was used to produce orthogonal array of attribute combinations. Orthoplan procedure of SPSS reduces the number of questions to be asked and, at the same time, gather adequate information for full analysis. The plancard procedure of SPSS generates sets of cards used in the study. These cards containing a combination of attributes were sorted out and will be ranked by the respondents after a question is asked. Conjoint procedure using SPSS requires (1) plan file which consists of sets of attribute profiles rated by the respondent, and (2) data file which contains the respondent's rankings of profiles or their preference scores. Generate Orthogonal Design procedure was used to generate results from the plan file.

The creation of the plancards circumvents the individuality of each variable. Respondents need to look at the situation as a whole (i.e., a combination of each plancard) instead of the individual in-store element alone. Conjoint analysis method on preferred elements was achieved instead of the best combination of elements the respondents want in a retail store when shopping. Here, conjoint goodness of fit statistics was used to get the p-value. Person R, Kendall's tau, and Kendal's tau for holdouts were used. All p-values are less than 0.05 , both on capped and uncapped spending, suggesting that the fit is acceptable, and the results are accurate and reliable. In determining the preferred level, the higher the value (positive) of the utility estimate, the most preferred the factor is.

\section{3- Conclusion}

As shown in Table 2, the four most influential retail elements with the degree of importance on a capped spending are (1) presence of directional signage at 25.08, (2) high level of product assortment at 16.47, (3) wide isles on store layout at 15.84, and (4) high level of replenishment rate at 13.74. The larger the value, the most important is the factor to the consumers. Moreover, the item with the highest 
value of importance, the more important the factor is. Thus, these elements are the most influential and prime the customers when buying from a physical store on a capped spending.

However, the second study shows a slightly different outcome. As shown in Table 3, the four most influential retail elements for consumers when shopping with the degree of importance on uncapped spending are (1) presence of directional signage at 22.38, (2) presence of product bundle at 21.88, (3) high level of product assortment at 19.14, and (4) high level of replenishment rate at 10.07. Although the most preferred element by the consumers is still the presence of directional signage, the presence of product bundle replaced the high level of product assortment on uncapped spending.

Findings from the capped spending scenario suggest that the retailing elements that influence the buying decisions do not need a high level of resources. Surprisingly, many firms spend a high level of resources to increase their sales for a very long time. However, the results show that non-cost and nonprice-related physical retail store elements are most preferred by the customers when shopping on a capped spending. On the other hand, findings from the uncapped spending scenario suggest that the presence of directional signages still influence the customers in their buying decisions with the highest degree of importance. Nevertheless, in this scenario, high level of product assortment was replaced by the presence of product bundle. This is not surprising due to the uncapped spending condition and that the customers are willing to buy when promotion, such as product bundle, is present in the trading floor. This shows that customers are more prone to promotion such as product bundle and they are willing to buy more when there is no spending limit specified.

While the physical store elements are considered default in a physical store setting, the original perspective is that the more resources you throw at an element, the more impactful it is in terms of influencing purchase behavior. The unplanned or impulse buying of customers is reliant on the efficacy of the marketing strategies both by the manufacturers and retailers. Although many firms spend costly marketing activities or tools to entice customers on impulse or to buy more, the results revealed that customers prefer non-cost marketing activities or tools when shopping grocery items. In-store touchpoint elements do influence customer's buying behavior at some extent. It is worth noting that in making retail environment decisions, it is important to remember that spending more money on physical store elements will not automatically translate into favorable customer's buying outcomes. Moreover, a firm should place heavier emphasis on efficient management of non-cost and non-price-related marketing activities or tools that resembles the top four findings in the capped spending scenario. Furthermore, given the outcomes, the relationship between retailers and manufacturers should also be reviewed. Nevertheless, both manufacturers and retailers must consider the right timing before deploying the price-related marketing activities to lessen the costs and to maximize efficacy, sales and profit in using these physical in-store elements.

\section{References}

[1] Ainsworth, J., Foster, J. (2017). Comfort in brick and mortar shopping experiences: Examining antecedents and consequences of comfortable retail experiences. Journal of Retailing and Consumer Services, 35, 27-35. 
[2] Atulkar, S. \& Kesari, B. (2017). Satisfaction, loyalty and repatronage intentions: Role of hedonic shopping values. Journal of Retailing and Consumer Services, 39, 23-34.

[3] Bayer, R-C. \& Ke, C. (2013). Discounts and consumer search behavior: The role of framing. Journal of Economic Psychology, 39, 215-224.

[4] Behe, B. K., Bae, M., Huddleston, P.T. \& Sage, L. (2015). The effect of involvement on visual attention and product choice. Journal of Retailing and Consumer Services, 24, 10-21.

[5] Beneke, J., Cumming, A. \& Jolly, L. (2013). The effect of item reduction on assortment satisfaction-A consideration of category of red wine in a controlled retail setting. Journal of Retailing and Consumer Services, 20, 282-291.

[6] Berman, B. \& Evans, J. R. (2010). Retail management: A strategic approach (11 ${ }^{\text {th }}$ ed.). Pearson Education Inc., Prentice Hall.

[7] Bogomolova, S., Szabo, M. \& Kennedy, R. (2017). Retailers' and manufacturers' pricepromotion decisions: Intuitive or evidence-based? Journal of Business Research, 76, 189200.

[8] Breugelmans, E. \& Campo, K. (2016). Cross-channel effects of price promotions: An empirical analysis of the multi-channel grocery retail sector. Journal of Retailing, 92(3), 333-351.

[9] Chan, E. Y. (2015). Attractiveness of options moderates the effect of choice overload. Intern. Journal of Research in Marketing, 32, 425-427.

[10] Chebat, J. C., Michon, R., Haj-Salem, N. \& Oliveira, S. (2014). The effects of mall renovation on shopping values, satisfaction and spending behavior. Journal of Retailing and Consumer Services, 21, 610-618.

[11] Clement, J., Kristensen, T., \& Grønhaug, K. (2013). Understanding consumers’ in-store visual perception: The influence of package design features on visual attention. Journal of Retailing and Consumer Services, 20, 234-239.

[12] Coughlan, A.T., Anderson, E., Stern, L.W. \& El-Ansary, A.I. (2010). Comprehensive study of marketing channels $\left(7^{\text {th }}\right.$ ed.). Pearson Education Inc., Prentice Hall.

[13] Diels, J. L., Wiebach, N. \& Hildebrandt, L. (2013). The impact of promotions on consumer choices and preferences in out-of-stock situations. Journal of Retailing and Consumer Services, 20, 587-598.

[14] Euromonitor International (2019a). Consumer types in the Philippines. Retrieved February 2020, from http://0-www.portal.euromonitor.com.ustlib.ust.edu.ph/ portal/analysis/tab.

[15] Euromonitor International (2019b). Supermarkets in the Philippines. Retrieved February 2020, from http://0-www.portal.euromonitor.com.ustlib.ust.edu.ph/ portal/analysis/tab. 
[16] Foster, J. \& McLelland, M. A. (2015). Retail atmospherics: The impact of a brand dictated theme. Journal of Retailing and Consumer Services, 22, 195-205.

[17] Furnham, A. \& Milner, R. (2013). The impact of mood on customer behavior: Staff mood and environmental factors. Journal of Retailing and Consumer Services, 20, 634-641.

[18] Gao, L. \& Simonson, I. (2016). The positive effect of assortment size on purchase likelihood: The moderating influence of decision order. Journal of Consumer Psychology, 26(4), 542549.

[19] Garaus, M., Wagner, U. \& Kummer, C. (2015). Cognitive fit, retail shopper confusion, and shopping value: Empirical investigation. Journal of Business Research, 68, 1003-1011.

[20] Garaus, M., Wagner, U. \& Manzinger, S. (2017). Happy grocery shopper: The creation of positive emotions through affective digital signage content. Technological Forecasting and Social Change, 124, 295-305.

[21] Grosso, M., Castaldo, S., Grewal, A. (2018). How store attributes impact shoppers' loyalty in emerging countries: An investigation in the Indian retail sector. Journal of Retailing and Consumer Services, 40, 117-124.

[22] Helmefalk, M. \& Hultén, B. (2017). Mult-sensory congruent cues in designing retail store atmosphere: Effects on shoppers' emotions and purchase behavior. Journal of Retailing and Consumer Services, 38, 1-11.

[23] Hoek, A.C., Pearson, D., James, S.W., Lawrence, M.A. \& Friel, S. (2017). Healthy and environmentally sustainable food choices: Consumer responses to point-of-purchase actions. Food Quality and Preference, 58, 94-106.

[24] Horstmann, F. (2017). Measuring the shopper's attitude toward the point of sale display: Scale development and validation. Journal of Retailing and Consumer Services, 36, 112-123.

[25] Huang, Y. \& Zhang, Y.C. (2016). The Out-of-Stock (OOS) effect on choice shares of available options. Journal of Retailing, 92(1), 13-24.

[26] Hynes, N. \& Manson, S. (2016). The sound of silence: Why music in supermarkets is just a distraction. Journal of Retailing and Consumer Services, 28, 171-178.

[27] Inman, J. J. \& Nikolova, H. (2017). Shopper-facing retail technology: A retailer adoption decision framework incorporating shopper attitudes and privacy concerns. Journal of Retailing, 93(1), 7-28.

[28] Ketron, S., Spears, N. \& Dai, B. (2016). Overcoming information overload in retail environments: Imagination and sales promotion in a wine context. Journal of Retailing and Consumer Services, 33, 23-32. 
[29] Kukkar-Kinney, M. \& Carlson, J. R. (2015). A fresh look at consumers' discounting of discounts in online and bricks-and-mortar shopping contexts. International Journal of Research in Marketing, 32, 442-444.

[30] Kumar, A. \& Kim, Y. (2014). The store-store-as-a-brand strategy: The effect of store environment on customer responses. Journal of Retailing and Consumer Services, 21, 685695.

[31] Kuntner, T. \& Teichert, T. (2016). The scope of price promotion research: An informetric study. Journal of Business Research, 69, 2687-2696.

[32] Langner, T. \& Krengel, M. (2013). The mere categorization effect for complex products: The moderating role of expertise and affect. Journal of Business Research, 66, 924-932.

[33] Lawley, M., Birch, D. \& Johnson, L. (2016). Changing purchasing habits through non-monetary point of sale strategies: The case of Australian oysters. Journal of Retailing and Consumer Services, 33, 194-201.

[34] Liu, H. \& Chou, H. (2015). The effects of promotional frames of sales packages on perceived price increases and repurchase intentions. International Journal of Research in Marketing. $32,23-33$

[35] Loureiro, S. M. C. \& Roschk, H. (2014). Differential effects of atmospheric cues on emotions and loyalty intention with respect to age under online/offline environment. Journal of Retailing and Consumer Services, 21, 211-219.

[36] Lu, H., Hess, S., Daly, A. \& Rohr, C. (2017). Measuring the impact of alcohol multi-buy promotions on consumers' purchase behavior. The Journal of Choice Modelling, 24, 75-95.

[37] Lu, X., Phang, C. W., Ba, S. \& Yao, X. (2018). Know who to give: Enhancing the effectiveness of online product sampling. Decision Support Systems, 105, 77-86.

[38] Michel, A., Baumann, C. \& Gayer, L. (2017). Thank you for the music - or not? The effects of in-store music in service settings. Journal of Retailing and Consumer Services, 36, 21-32.

[39] North, A.C., Sheridan, L.P. \& Areni, C.S. (2016). Music congruity effects on product memory, perception, and choice. Journal of Retailing, 92(1), 83-95.

[40] Orme, B. (2010) Getting Started with Conjoint Analysis: Strategies for product design and pricing research $\left(2^{\text {nd }}\right.$ ed.). Research Publishers LLC.

[41] Otterbring, T., Wästlund, E. \& Gustafsson, A. (2016). Eye-tracking customers' visual attention in the wild: Dynamic gaze behavior moderates the effect of store familiarity on navigational fluency. Journal of Retailing and Consumer Services, 28, 165-170. 
[42] Otterbring, T., Wästlund, E. \& Gustafssson, A., Shams, P. (2014). Vision (im)possible? The effects of in-store signage on customers' visual attention. Journal of Retailing and Consumer Services, 21, 676-684.

[43] Pantano, E. (2016). Engaging consumer through the storefront: Evidences from integrating interactive technologies. Journal of Retailing and Consumer Services, 28, 149-154.

[44] Pantano, E. \& Viassone, M. (2014). Demand pull and technology push perspective in technology-based innovations for the points of sale: The retailers evaluation. Journal of Retailing and Consumer Services, 21, 43-47.

[45] Parment, A. (2013). Generation Y vs. baby boomers: Shopping behavior, buyer involvement, and implications to retailing. Journal of Retailing and Consumer Services, 20, 189-199.

[46] Pizzi, G. \& Scarpi, D. (2013). When out-of-stock products do backfire: Managing disclosure time and justification wording. Journal of Retailing, 89(3), 352-359.

[47] Platania, M., Platania, S. \& Santisi, G. (2016). Entertainment marketing, experiential consumption and consumer behavior: The determinant of choice of wine in the store. Wine Economics and Policy, 5, 97-95.

[48] Poncin, I. \& Ben Mimoun, M.S. (2014). The impact of “e-atmospherics" on physical stores. Journal of Retailing and Consumer Services, 21, 851-859.

[49] Pride, W. M., Ferrel, O. C. \& Hult, G. T. M. (2013). Marketing foundations. Cengage Learning Asia Pte Ltd.

[50] Rayburn, S. W. \& Voss, K.E. (2013). A model of consumer's retail atmosphere perceptions. Journal of Retailing and Consumer Services, 20, 400-407.

[51] Roschk, H., Loureiro, S.M.C. \& Breitsohl, J. (2017). Calibrating 30 years of experimental research: A meta-analysis of the atmospheric effects of music, scent, and color. Journal of Retailing, 93(2), 228-240.

[52] Scriven, J., Clemente, M., Dawes, J., Trinh, G. \& Sharp, B. (2017). Buying brands at both regular price and on promotion over time. Australasian Marketing Journal, 25, 252-260.

[53] Shimp, T.A. \& Andrews, J. C. (2014a). Advertising, promotion and other aspects of integrated marketing communications $\left(9^{\text {th }}\right.$ ed.). Cengage Learning Asia Pte Ltd.

[54] Shimp, T.A. \& Andrews, J. C. (2014b). Advertising, promotion and other aspects of integrated marketing communications (2013-2015 ed.). Cengage Learning Asia Pte Ltd.

[55] Spassova, G. \& Isen, A. M. (2013). Positive effect moderates the impact of assortment size on choice satisfaction. Journal of Retailing, 89(4), 397-408. 
[56] Stein, A. \& Ramaseshan, B. (2016). Towards the identification of customer experience touch point elements. Journal of Retailing and Consumer Services, 30, 8-19.

[57] Terblanche, N. S. (2018). Revisiting the supermarket in-store customer shopping experience. Journal of Retailing and consumer Services, 40, 48-59.

[58] Vieira, V. A. \& Torres, C. V. (2014). The effect of motivational orientation over arousalshopping response relationship. Journal of Retailing and Consumer Services, 21, 158-167.

[59] Vilches-Montero, S., Nik Hashim, N. M. H., Pandit, A. \& Bravo-Olavarria, R. (2018). Using the senses to evaluate aesthetic products at the point of sale: The moderating role of consumers' goals. Journal of Retailing and Consumer Services, 40, 82-90.

[60] Vyt, D., Jara, M. \& Cliquet, G. (2017). Grocery pickup creation of value: Customers' benefits vs. spatial dimensions. Journal of Retailing and Consumer Services, 39, 145-153.

[61] Wang, S. \& Lang, M. (2015). The effects of special displays on shopping behavior. Journal of Retailing and Consumer Services, 23, 125-132.

[62] Yan, H., Chang, E.-C., Chou, T.-J. \& Tang, X. (2015). The over-categorization effect: How the number of categorizations influences shoppers' perceptions of variety and satisfaction. Journal of Business Research, 68, 631-638.

[63] Yan, R., Myers, C., Wang, J. \& Ghose, S. (2014). Bundling products to success: The influence of complementarity and advertising. Journal of Retailing and Consumer Services, 21, 48-53.

[64] Yao, X., Lu X., Phang C. W. \& Ba, S. (2017). Dynamic sales impacts of online physical product sampling. Information and Management, 54, 599-612. 


\section{Appendix}

\section{Table 1}

\section{Plancards for Conjoint Analysis}

\begin{tabular}{|c|c|c|c|c|c|c|c|c|c|}
\hline & $\begin{array}{c}\text { Card } \\
\text { ID } \\
(\text { Code })\end{array}$ & $\begin{array}{l}\text { Product } \\
\text { Sample }\end{array}$ & $\begin{array}{l}\text { Product } \\
\text { Bundle }\end{array}$ & $\begin{array}{c}\text { Store } \\
\text { Layout }\end{array}$ & $\begin{array}{l}\text { In-Store } \\
\text { Music }\end{array}$ & $\begin{array}{c}\text { Directional } \\
\text { Signage }\end{array}$ & $\begin{array}{l}\text { Shelf } \\
\text { Talker }\end{array}$ & $\begin{array}{c}\text { Replenishment } \\
\text { Rate }\end{array}$ & $\begin{array}{c}\text { Product } \\
\text { Assortment }\end{array}$ \\
\hline 1 & $\mathrm{C} 1$ & Absent & Present & $\begin{array}{l}\text { Narrow } \\
\text { aisles }\end{array}$ & Present & Absent & Absent & Low & High \\
\hline 2 & $\mathrm{C} 2$ & Absent & Absent & $\begin{array}{l}\text { Narrow } \\
\text { aisles }\end{array}$ & Absent & Present & Present & Low & High \\
\hline 3 & C3 & Present & Present & $\begin{array}{l}\text { Narrow } \\
\text { aisles }\end{array}$ & Absent & Present & Present & High & High \\
\hline 4 & $\mathrm{C} 4$ & Present & Present & $\begin{array}{l}\text { Wide } \\
\text { aisles }\end{array}$ & Present & Absent & Present & High & High \\
\hline 5 & $\mathrm{C} 5$ & Absent & Present & $\begin{array}{l}\text { Wide } \\
\text { aisles }\end{array}$ & Absent & Absent & Present & Low & Low \\
\hline 6 & C6 & Present & Present & $\begin{array}{l}\text { Wide } \\
\text { aisles }\end{array}$ & Absent & Present & Absent & Low & Low \\
\hline 7 & C7 & Absent & Absent & $\begin{array}{l}\text { Wide } \\
\text { aisles }\end{array}$ & Present & Present & Present & High & Low \\
\hline 8 & $\mathrm{C} 8$ & Present & Absent & $\begin{array}{l}\text { Wide } \\
\text { aisles }\end{array}$ & Present & Present & Absent & Low & High \\
\hline 9 & C9 & Present & Absent & $\begin{array}{l}\text { Narrow } \\
\text { aisles }\end{array}$ & Present & Absent & Present & Low & Low \\
\hline 10 & C10 & Present & Absent & $\begin{array}{l}\text { Narrow } \\
\text { aisles }\end{array}$ & Absent & Absent & Absent & High & Low \\
\hline 11 & C11 & Absent & Present & $\begin{array}{l}\text { Narrow } \\
\text { aisles }\end{array}$ & Present & Present & Absent & High & Low \\
\hline 12 & C12 & Absent & Absent & $\begin{array}{l}\text { Wide } \\
\text { aisles }\end{array}$ & Absent & Absent & Absent & High & High \\
\hline $13^{a}$ & C13 & Absent & Present & $\begin{array}{l}\text { Wide } \\
\text { aisles }\end{array}$ & Present & Present & Absent & High & High \\
\hline $14^{\mathrm{a}}$ & C14 & Absent & Absent & $\begin{array}{l}\text { Wide } \\
\text { aisles }\end{array}$ & Present & Absent & Absent & High & High \\
\hline $15^{\mathrm{a}}$ & C15 & Absent & Absent & $\begin{array}{l}\text { Narrow } \\
\text { aisles }\end{array}$ & Absent & Absent & Present & High & Low \\
\hline $16^{a}$ & C16 & Absent & Present & $\begin{array}{l}\text { Wide } \\
\text { aisles }\end{array}$ & Present & Absent & Absent & High & High \\
\hline
\end{tabular}

${ }^{a}$ Holdout cards 
Table 2

Preference of The Respondents on a Condition of Grocery Shopping on Capped Spending

\begin{tabular}{|c|c|c|c|c|c|}
\hline \multicolumn{2}{|c|}{ Factors/Levels } & \multirow{2}{*}{$\begin{array}{c}\text { Utility Estimate } \\
0.80 \\
\end{array}$} & \multirow{2}{*}{$\begin{array}{l}\text { S.E. } \\
0.08 \\
\end{array}$} & \multirow{3}{*}{$\begin{array}{c}\text { Importance } \\
25.08\end{array}$} & \multirow{3}{*}{$\begin{array}{c}\text { Rank } \\
1^{\text {st }}\end{array}$} \\
\hline \multirow[t]{2}{*}{ Directional Signage } & Present & & & & \\
\hline & Absent & -0.80 & 0.08 & & \\
\hline \multirow[t]{2}{*}{ Product Assortment } & High & 0.52 & 0.08 & \multirow[t]{2}{*}{16.47} & \multirow[t]{2}{*}{$2^{\text {nd }}$} \\
\hline & Low & -0.52 & 0.08 & & \\
\hline \multirow[t]{2}{*}{ Store Layout } & Narrow aisles & -0.50 & 0.08 & \multirow[t]{2}{*}{15.84} & \multirow[t]{2}{*}{$3^{\text {rd }}$} \\
\hline & Wide aisles & 0.50 & 0.08 & & \\
\hline \multirow[t]{2}{*}{ Replenishment Rate } & High & 0.44 & 0.08 & \multirow[t]{2}{*}{13.74} & \multirow[t]{2}{*}{$4^{\text {th }}$} \\
\hline & Low & -0.44 & 0.08 & & \\
\hline \multirow[t]{2}{*}{ Product Sample } & Present & 0.37 & 0.08 & \multirow[t]{2}{*}{11.50} & \multirow[t]{2}{*}{$5^{\text {th }}$} \\
\hline & Absent & -0.37 & 0.08 & & \\
\hline \multirow[t]{2}{*}{ Music } & Absent & -0.30 & 0.08 & \multirow[t]{2}{*}{9.60} & \multirow[t]{2}{*}{$6^{\text {th }}$} \\
\hline & Present & 0.30 & 0.08 & & \\
\hline \multirow[t]{2}{*}{ Product Bundle } & Present & 0.20 & 0.08 & \multirow[t]{2}{*}{6.26} & \multirow[t]{2}{*}{7 th } \\
\hline & Absent & -0.20 & 0.08 & & \\
\hline \multirow[t]{2}{*}{ Shelf Talker } & Present & 0.05 & 0.08 & \multirow[t]{2}{*}{1.51} & \multirow[t]{2}{*}{$8^{\text {th }}$} \\
\hline & Absent & -0.05 & 0.08 & & \\
\hline Constant & & 6.49 & 0.08 & & \\
\hline \multicolumn{6}{|c|}{ Conjoint Goodness of Fit Statistics: } \\
\hline \multicolumn{6}{|c|}{ Pearson $R=.994, p=.000$} \\
\hline \multicolumn{2}{|c|}{$\begin{array}{l}\text { Kendall's } \\
\text { Kendal's tau for holdouts }=1.00, p=.021\end{array}$} & $=$ & \multicolumn{2}{|c|}{.879} & $p=.000$ \\
\hline
\end{tabular}


Table 3

Preference of the Respondents on the Condition of the Grocery Shopping on Uncapped Spending

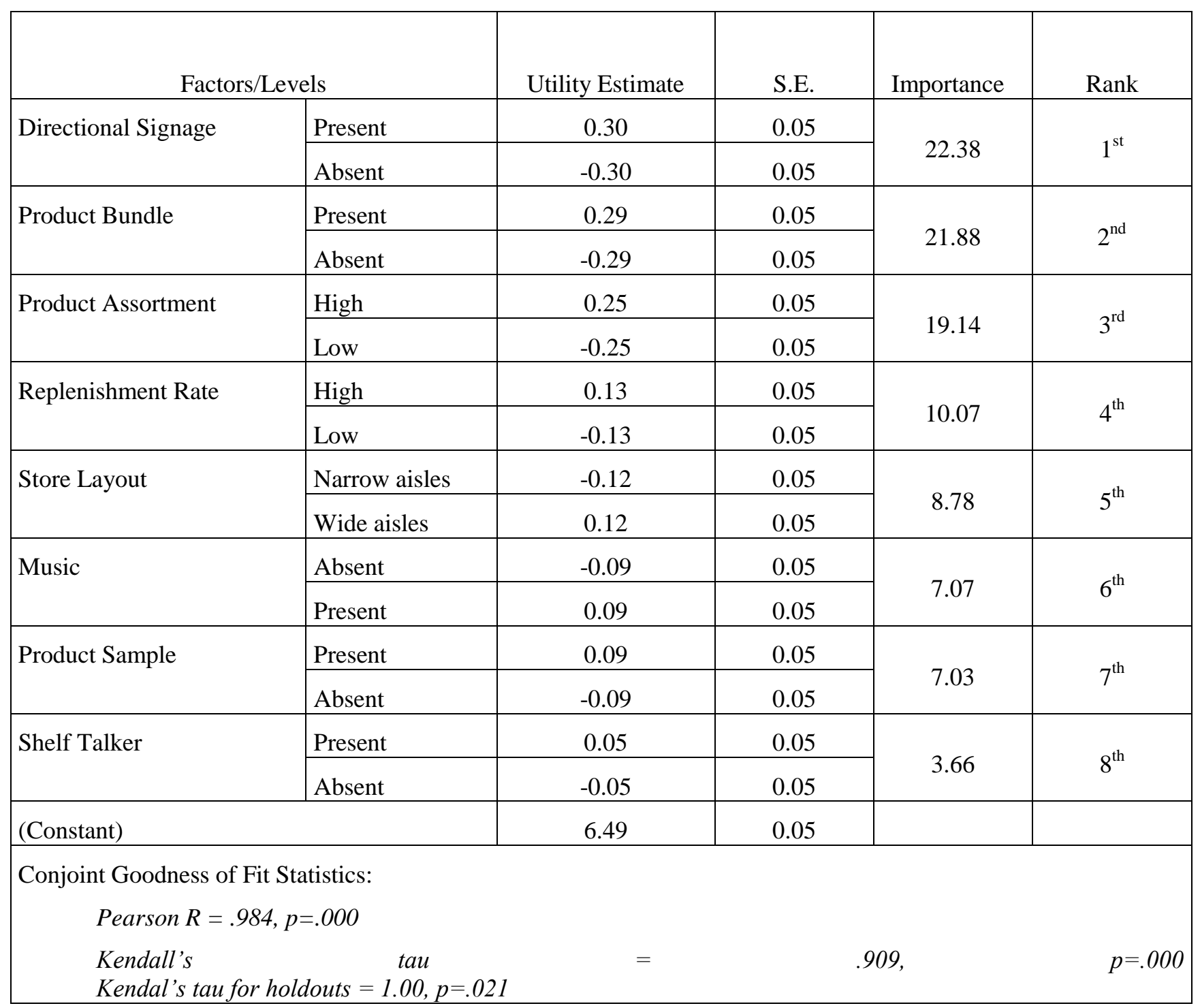

